\title{
Küçük Devlet Kuramı ve Ceenbekov Dönemi Kırgız Dış Politikasının Dinamikleri
}

\author{
Small State Theory and Dynamics of Kyrgyz, Foreign Policy in Ceenbekov Period \\ Mustafa Cüneyt Özşahin a,* \\ ${ }^{a}$ Dr. Öğr. Üyesi, Necmettin Erbakan Üniversitesi, Siyasal Bilgiler Fakültesi, Uluslararası İlişkiler Bölümü, 42090, Konya/Türkiye \\ ORCID: 0000-0002-3445-5412
}

\section{MAKALE BİLGİSİ}

Makale Geçmişi:

Başvuru tarihi: 22 Ekim 2019

Düzeltme tarihi: 17 Mart 2020

Kabul tarihi: 05 Nisan 2020

Anahtar Kelimeler:

Kirgizistan,

Diş Politika,

Küçük Devlet,

Ceenbekov

\section{ARTICLE INFO}

\section{Article history:}

Received 22 October 2019

Received in revised form 17 March 2020

Accepted 05 April 2020

Keywords:
Kyrgyzstan,
Foreign Policy,
Small State,
Jeenbekov

ÖZ

Ceenbekov dönemi Kırgız dış politikasının ele alındığı bu çalışmada ilgili dönemde dış politikada belirgin bir kırılmanın yaşanmadığı iddia edilmektedir. Bu çerçevede Kırgız dış politikasının gerçekleşen lider değişiminden bağımsız olarak süreklilik arz eden müesses yapıların keşfedilmesi vasıtasıyla doğru şekilde anlamlandırılacağı savlanmaktadır. Bu değerlendirmede küçük devlet yaklaşımı yardımıyla Ceenbekov dönemi dış politikası analiz edilmeye çalışılmaktadır. $\mathrm{Bu}$ kapsamda ABD'nin tedrici geri çekilişi sonucunda Ceenbekov döneminde de Rusya merkezli siyasetin kesintisiz devam ettiği iddia edilmektedir. Ayrıca küçük devlet kavramı etrafinda teorize edilen bu çalışmada Kırgızistan'ın bölgesel ve küresel güçlerle olan ilişkilerinin iç politikadan bağımsız olmadığı iddia edilecektir. Özetle, tüm bu değerlendirmeler ışığında, (Cooley, 2012), (Sarı, 2012) ve (Toktomushev, 2015, 2016)'in araştırmalarından faydalanılarak Ceenbekov dönemi dış politikası anlamlandırılmaya çalışılmaktadır.

\begin{abstract}
A B S T R A C T
By focusing on Kyrgyz's foreign policy during the Jeenbekov period, this study argues that there has been no structural break from the past in terms of the direction of foreign policy. Within this framework, it is propounded that Kyrgyz foreign policy can only be explained in terms of some underlying establishments independent of leadership change. In this research, the Jeenbekov period in Kyrgyz's foreign policy was examined using a small state perspective. Within this framework, it is asserted that the Russia-centric foreign policy of Kyrgyzstan continued in the Jeenbekov period as a result of the gradual withdrawal of the United States. Moreover, it is claimed that Kyrgyzstan's relationship with global and regional powers is by no means detached from her domestic politics. In summary, in the light of these considerations, this study aims to make sense of the foreign policy of Jeenbekov period by drawing on the research of (Cooley, 2012), (Sar1, 2012) and (Toktomushev, 2015, 2016).
\end{abstract}

\section{Giriş}

SSCB mirasının taşıyıcılığını üstlenen ve bu mirasın olumsuzlukları ile yüzleşmek zorunda kalan ülkelerden biri de kuşkusuz Kırgızistan'dır. Muhtelif aidiyetlerin harmanlandığı bir kültür havzası olmakla beraber, Orta Asya coğrafyası aynı zamanda bu aidiyetlerin sıklıkla çatıştığı patlamaya hazır bir barut fiçısını andırır. Öyle ki ulus devlet sınırlarını aşan Kırgız ve Özbek kimlikleri her iki ülke için de farklı gerilimleri beslemektedir. Öte yandan yoksulluk ve yolsuzluğun yaygınlığı bölge ekonomilerinin istikrarı yakalamasının önünde büyük bir engel olarak durmaktadır. Kırgızistan bu çerçevede büyük oranda işçi dövizlerine ve dış yardımlara bağlı doğal kaynaklar bakımından ise sınırlı bir ülke mahiyetindedir. Dış politika ise tüm bu olumsuzlukların gölgesinde teşekkül etmekte ve yukarıda sıralanan sorunlardan bağımsız bir nitelik arz etmemektedir. $\mathrm{Bu}$ çerçevede bölge ülkeleri arasında teritoryal anlaşmazlıkların yanı sıra, enerji ve su kaynaklarının paylaşımına ilişkin konular bölgenin donmuş meseleleri olarak bir kenarda durmaktadır. Sinırlı kaynaklara sahip olan ve pek çok anlamda hassas bir jeopolitiğe sahip olan Kırgızistan bu çerçevede gerek komşuları gerekse de bölgesel güçler ile muvazeneli bir ilişki yürütmek zorunda kalmıştır. Ayrıca sırasıyla 2005 ve 2010 yılında gerçekleşen iki farklı kitle hareketi, Kırgızistan'da iç politik istikrarın

\footnotetext{
* Sorumlu yazar/Corresponding author.

e-posta: mustafacuneytozsahin@gmail.com.
} 
sanıldığından çok daha kırılgan olduğunu ortaya koymaktadır.

$\mathrm{Bu}$ çalışmada Atambayev sonrası Kırgızistan dış politikasının nasıl şekillenmekte olduğuna ilişkin genel bir çerçeve sunulmaya çalışılacaktır. Bu kapsamda küçük devlet yaklaşımından faydalanılarak Ceenbekov'un diş politika yönelimi analiz edilmektedir. Diş politikada değişimden ziyade bir devamlılığa vurgu yapilan bu analizde Kırgızistan'da lider değişimi kaynaklı bir dış politika değişimi yaşanmadı̆̆ı, dış politikanın farklı liderlerin iktidarlarında küçük devletlere özgü sınırlılıklar etrafında devam ettiği vurgulanmaktadır. Bu minvalde konuyla ilgili literatürün Türkçeye kazandırıldığı bu çalışma ile iç politikanın yapısal kırılganlığının dış politikaya tesiri tartışmaya açılmaktadır. Ayrıca ABD’nin Orta Asya'dan tedrici olarak çekilmesi ile beraber son yıllarda artan Rus etkisinin Kırgızistan siyasetinde belirleyici olduğu savunulmaktadır. Çizilen bu çerçevede birinci bölümde Kırgızistan'da son dönemde yaşanan siyasal dönüşümün kısa bir değerlendirilmesi yapılmakta, ikinci bölümde Kırgız dış politikasının teorik zeminine ilişkin küçük devlet yaklaşımı bağlamında bir analiz yapılmakta, son bölümde ise genel bir özet ve değerlendirme sunulmaktadır.

\section{2010 Sonrası Kırgız Dış Politikasında Gelișmeler: Ceenbekov Dönemi Dıș Politikasının Temel Dinamikleri}

2005 Lale Devrimi ve ardından 2010 y1lında patlak veren halk isyanları Kırgızistan'da siyasal ve sosyal dengelerin ne derece hassas olduğunun işaretlerini sundu. Sovyetlerin çözülmesinin ardından Askar Akayev'e müteakip 2005 devrimi sonrası Kurmanbek Bakiyev'in göreve gelmesi Kırgızistan'ın iç politikasında büyük beklentilerin önemli bir dönüşüm olarak kabul edilmiştir (Coldoşov, 2017: 262-263). Ancak bu değişim iç politikayla sınırlı kalmamış, Kırgız dış politikasında bir yenilenmeyi de beraberinde getirmiştir. Akayev ile başlayan ve Bakiyev dönemine tevarüs eden bölgenin iki önemli gücü $A B D$ ve Rusya arasında izlenen denge politikası, kimilerince çok vektörlü diplomasi olarak adlandırılmıştır (Huskey, 2008: 9; Muzalevsky, 2010; Sarı, 2012: 139). Benzer bir vurgu yapan Çotaev (2017: 355-356) ise değerlendirmesinde çok vektörlü değil çok yönlü dış politika ifadesini tercih etmektedir. Söz konusu politikanın somut yansiması ise ABD'nin Kirgizistan'da konuşlandırdığı ve Rusya'nın tepkisine neden olan askeri üssü olmuştur. Rusya ve ABD arasındaki çekişmenin en yoğun yaşandığı bu dönemin ardından taraflar arasındaki gerilim 2010 sonrasında kademeli olarak yatışmıştır. Bakiyev'in uzaklaştırılması ve yerini Atambayev'e bırakması Rusya'nın yeniden bölgesel hegemonyasını tesis etmesine zemin teşkil etmiştir. Atambayev bu çerçevede ABD’nin askeri üssünü kapatmakla kalmamış aynı zamanda Rusya'nın bir girişimi olan Avrasya Ekonomik Birliğine de dâhil olmuştur (Toktomushev, 2015; Toktomushev, 2016: 165-168). Nitekim Atambayev tarafindan tutuklanan Kırgiz muhalefetinin önemli isimlerinden Tekebayev, 2010 olaylarında Rus etkisini "Rusya'nın Bakiyev gittiğinde ne kadar mutlu olduğunu gördünüz" diyerek ortaya koymuştur (Golovnina ve Solovyov, 2010).

Yaşanan çalkantılı döneme müteakip Atambayev 2011 yılında devlet başkanlığı görevini üstlenmiş, görev süresinin bittiği 2017 yılında ise ülke yeni bir seçime gitmiştir. 15
Ekim 2017 seçimlerinde ilk sırada yer almayı başaran Sooronbay Ceenbekov Kasım ayında Kırgızistan devlet başkanı olarak görevine başlamıştır (BBC, 2018). Seçim sürecinde kendinden önce devlet başkanlığını üstlenen Atambayev'in desteğini alan Ceenbekov tahminlerin aksine Atambayev'in yörüngesinde bir siyaset izlememiştir. Nitekim ilerleyen süreçte Atambayev ve Ceenbekov arasındaki ilişki sekteye uğramış, Atambayev'in kurmaya çalıştığı vesayet ilişkisi taraflar arasında çatışma ile sonuçlanmıştır. Neticede Atambayev "yolsuzluk, görevi kötüye kullanma ve cinayet suçlarıyla" derdest edilmiş ve siyaset sahnesinden tamamen çekilmiştir (Euroasianet, 2019).

İktidarını konsolide etmesi ile beraber Ceenbekov gerek iç gerek dış politikada bir takım adımlar atmıştır. Bu çerçevede kendi döneminde Ceenbekov, 30 ziyaretin yanı sıra 77 ikili, 414 çoklu anlaşma imzalamıştır (MENAFN - Trend News Agency, 2018). Öte yandan Atambayev sonrası dönemde Kırgız dış politikasının dinamiklerinin ciddi bir kırılma yaşadığını iddia etmek güçtür. $\mathrm{Bu}$ dönemde izlenen dış politikanın bundan önce olduğu gibi küçük devlet yaklaşımı çerçevesinde anlamlandırılması mümkündür. Akayev ve Bakiyev döneminin temel karakteristiğini yansıtan çok vektörlü dış politikanın aksine gerek Atambayev gerekse de 2017'den bu yana iktidarda bulunan Ceenbekov döneminde Kırgızistan Rusya merkezli bir dış politika izleme yolunu tercih etmiştir. Ceenbekov diş politikanın değişmeyeceğini özellikle Rusya ile ilişkilere yaptığı vurgu ile ortaya koymaktadır (Radio Free Europe/ Radio Liberty, 2018). Nitekim Kırgızistan'ın Atambayev döneminde üyeliğine kabul edildiği Avrasya Ekonomik Birliği, Ceenbekov tarafından övgüyle karşılanmıştır (Kabar, 2019). Bu çalışmada küçük devlet kuramından faydalanılarak Kırgızistan'ın Rusya merkezli siyasetinin kaynağı gerek iç politikanın dayandığı neopatrimonyal ilişkiler gerekse de ABD'nin bölgeden kademeli geri çekilme siyaseti izlemesi çerçevesinde anlamlandırılmaktadır.

\section{Küçük Devlet Kuramı ve Kırgız Dış Politikası}

Bu çalışma Hermann'a ait lider değişiminin diş politikayı değiştirilebileceği fikrine (Hermann, 1990:11) karşı dış politik değişimin yapısal kaynaklarına eğilecektir. Bu düzlemde Atambayev'den Ceenbekov'a devredilen iktidarın ne dış politikanın yönelimini ne de işleyişini değiştirmediği iddia edilmektedir. Alternatif bir teorik yaklaşım sunulan bu değerlendirmede Kırgızistan dış politikasının işleyişine sirayet etmiş yapısal dinamikler küçük devlet yaklaşımı çerçevesinde anlamlandırılmaya çalışılacaktır. Yine küçük devletlerin birbiriyle bağlantılı olan içsel ve dişsal kırılganlıklarının büyük oranda dış politikaya şekil vermekte olduğu iddia edilmektedir. Ancak detaylı bir analiz öncesinde küçük devlet kavramı üzerine bir değerlendirmede bulunmak anlam taşıyacaktır.

Küçük devlet pek çok açıdan tanımlanması güç bir kategori niteliğindedir. Üzerinde konsensüs sağlanmış bir küçük devlet tanımı olduğunu söylemek zordur. Öyle ki küçük devletlerin kendi içerisindeki çeşitliliği bizatihi kavramın analitik değerine gölge düşürdüğü iddia edilmektedir. Öyle ki küçük devlet tanımlaması içerisinde Avrupa'nın küçük nüfuslu zengin demokrasileri kadar azgelişmiş otokrasilerini de barındırmaktadır. Bu anlamda Avrupalı ve Avrupa dışı 
küçük devletler arasındaki farklar önem kazanmaktadır (bkz. Gibert ve Grzelczyk, 2016).

Öte yandan pek çok küçük devletin ekonomik ve askeri kırılganlıkları bu ülkelerin dış politika yapma biçimine de tesir etmiştir (Bkz. Yeşilyurt, 2015). Kuşkusuz bu kırılganlıklar aynı zamanda bağımlılık ilişkilerini de beraberinde getirmiştir. Özellikle azgelişmiş ülkelerin ekonomik bağımlılıkları dış politika yapma biçimlerinde belirleyici olduğunun altı çizilmektedir. (Moon, 2009). Yukarıda ortaya konulan çerçevede bu çalışma küçük devlet olgusunu gerek ekonomik gerekse de güvenlik bağlamında kırılganlıklara sahip ülkeleri tanımlamak için kullanılmaktadır (benzer bir tanım için bkz. Yeşilyurt, 2015). Daha açık bir ifadeyle genellikle Güney yarım kürede, ekonomik olarak dişa bağımlı ve güvenliğini sağlayamayan devletler bu çalışma çerçevesinde küçük devlet olarak tanımlanmıştır. Bu tanım büyük oranda Cooper ve Shaw (2009)'un küçük devlet yorumuyla uyuşmaktadır. Öyle ki yazarlara göre küçük devletler coğrafi, ekonomik ve idari olarak kırılganlıklara sahiptirler (Cooper ve Shaw, 2009: ix). Aynı şekilde bu çalışmada kullanılan kavramsallaştırma, Yeşilyurt (2015:388-394)'un küçük devletlerin siyasal, ekonomik ve askeri "incinebilirliğine" vurgu yaptığ değerlendirme ile paralellik arz etmektedir.

Genellikle altı çizilen konulardan bir diğeri de küçük devlet ve zayıf devletlerin literatürde birbirinin ikamesi olarak kullanılabildiğidir (Tür ve Salık, 2017:10). Zayıf devlet tanımı çerçevesinde diş politika davranışını anlamlandırmaya çalışan Handel ise bahse konu devletlerin dış politikalarının uluslararası politikanın dayattığı kısıtlar çerçevesinde şekillendiğinin ve iç politik karar alma sürecinin ise bu anlamda asgari bir rol oynadığının altını çizer. (Handel, 2016: 36). Ayrıca Handel, başta Waltz (1979) olmak üzere dengelemeyi öne çıkaran diğer neorealistlerin aksine potansiyel tehdit niteliğindeki güçlü devletlerin karşısında zayıf devletlerin boyun eğmeye yatkın olduğuna dikkat çeker (Handel, 2016: 26). Öte yandan Gleason vd. (2008) küçük devletlere yönelik analizlerinde realist teorinin varsayımları ve politika önerileri arasındaki açmazı Kırgızistan örneği üzerinden değerlendirir.

Bununla birlikte realizme yaslanmayan yaklaşımlar ise konuya ilişkin bir başka çerçeve çizmektedir. Nitekim bu kapsamda konuyla ilgili çalışmaların bir bölümü küçük devlerin cüsseleriyle orantılı olmayan bir biçimde uluslararası politikayı şekillendirilebilmekte olduğuna dikkat çekmektedir. Kimi çalışmalar Singapur ve Vatikan gibi ülkelerin uluslararası arenada üstlendikleri önemli diplomatik misyonlara yumuşak güç çerçevesinde vurgu yapmaktadır (Chong, 2010). Kimi diğer çalışmalar ise Avrupa kıtasındaki küçük devletlerin üstlendikleri, kapasitelerinin ötesindeki etkilerine temas etmektedir (Thorhallsson ve Wivel, 2006).

Öte yandan diğer araştırmalar bu ülkelerin diğer küresel ve bölgesel güçler ile girdikleri ittifak ilişkilerine odaklanmıştır. Küçük devletlerin üstlendikleri normatif misyonlara vurgu yapan çalışmaların yanı sıra güç ve güvenlik merkezli analizler, bu ülkeler açısından güvenlik açıklarını kapatmanın önemine işaret eder. Ö̈zellikle kırılganlıkları yüksek bu ülkeler için söz konusu arayış son derece hayatidir. Zira tanımı gereği kırılganlığın yüksek oluğu ülkeler aynı zamanda temel güvenlik kaygılarını çözememiş ülkeler olarak değerlendirilmelidir. Özellikle askeri ve ekonomik kaygıları azami düzeyde olan bu ülkeler için dış politika alternatifleri çok sınırlıdır (Handel, 2016: 36; Tür ve Salık, 2017:12-13). Askeri ve ekonomik bağımlılıklar geliştirmek bu anlamda pek çok ülke için tek çözüm yolu olarak ortaya çıkmıştır. Bu nedenledir ki pek çok küçük ülke, büyük ülkeleri bir "sığınak" olarak değerlendirmektedir (Bailes vd., 2016). Küçük devletlerin -özellikle de güçlü bir devletin desteğini almadığı durumlarda- denge politikası izlemesi ise bir diğer pozisyon olarak ortaya çıkmaktadır (Karsh, 2012: 4).

Bunun yanı sıra devletlerin askeri güçleri kadar ekonomik ve siyasal kırılganlıkları da göz önüne alınmalıdır (bkz. Yeşilyurt, 2015). Bir başka deyişle küçük devletlerin sistem içerisindeki maddi olanakları kadar devletlerin kurumsal dezavantajları da dış politika çıktılarında belirleyici olmaktadır. $\mathrm{Bu}$ nedenle küçük devletlerin diş politika davranışları konusunda kestirim yapmak için belirleyici pek çok değişkenin bir arada düşünülmesi elzemdir. Özellikle Batı dışı dünyada küçük devletlerin pek çoğu aynı zamanda zayıf devlet özellikleri sergilemekte ve modern bürokrasilerden yoksun oldukları akıldan çıkarılmamalıdır. $\mathrm{Bu}$ çerçevede siyasal kalkınma perspektifinden küçük devletler aynı zamanda gerek siyasal gerekse de ekonomik anlamda iyi yönetişimin sağlanamadığı ülkelerdir (Bishop, 2012; Brown, 2010; Sutton, 2011).

Kırgızistan pek çok açıdan küçük devlet özellikleri sergiler. Denize kapalı ve dağlık yapısının getirdiği dezavantajlar, enerji ve mineral kaynaklarının yokluğu yüzölçümü ve nüfusun küçüklüğü coğrafi ve demografik olarak ülkenin potansiyeline ket vurmaktadır (Huskey, 2008:6-7). Ayrıca kişi başı GSYİH dikkate alındığında Kırgızistan ekonomik olarak "orta altı gelire sahip ülke" kategorisi altında değerlendirilmektedir (Worldbank, 2019).

Bu kapsamda Kırgızistan'ın küçük devlet olma vasfina vurgu yapan geniş bir literatürün varlığından bahsetmek mümkündür (bkz. Gleason et al., 2008; Huskey, 2008; Sar1, 2012). İlgili çalışmalar kısaca gözden geçirilecek olursa, Toktomushev, (2016) küçük devletin muadili olarak zayıf devlet kavramını kullanmayı yeğlemiştir. Sarı (2012), ise Kırgızistan merkezli analizinde "küçük zayıf devlet (small weak state)" ifadesini tercih etmektedir. Huskey (2008:67)'de Kırgızistan için küçük devlet ifadesini kullanmakta bununla birlikte iç-dış siyaset bağlantısına yönelik kuramsal bir bağlam sunmamaktadır. Buna karşın, Sarı (2012) ve Toktomushev (2016) çalışmalarında Kırgızistan'ın bu zayıflığının dış politik yansımasını teorize edebilmiştir. Nitekim küçük devlet kuramına yönelik literatürde küçük devletlerin dış politikasının belirleyenlerine ilişkin iç politikanın birbiri ile benzeşmeyen pek çok farklı özelliğine vurgu yapılabilmektedir (bkz. Tür ve Salık, 2017: 15-18). Küçük devletlere ait yukarıda sunulan bu değerlendirmelere paralel olarak, müteakip kısımda Kırgızistan'ın gerek iç gerekse de dış kırılganlıklarının arka planı ve bunun Ceenbekov dönemi dış siyasetine yansımaları ele alınacaktır.

\section{1. İç Kırılganlık ve Neopatrimonyalizm}

Kırgızistan pek çok Orta Asya ülkesinin aksine zengin yeraltı kaynaklarına sahip olmayan ve bu çerçevede geleneksel anlamiyla rantiyer niteliğe sahip olmayan, buna karşın dış bağımlılı̆̆ı yüksek bir ülke niteliğindedir. Bir başka deyişle doğal kaynakların yetersizliği ve katma değer üreten bir ekonominin yokluğu mevcut iktidarların 
sürdürülmesi için dış kaynak transferini zorunlu hale getirmektedir (Alkan, 2012: 6-7). Bununla birlikte Kırgızistan'da varolan yoğun yolsuzluk sorunu devletler aygıtının kurumsallaşmasını engelleyerek, makamları kişisel iktidar alanlarına dönüştürmektedir. Siyaset ve ekonomik sektör genellikle informel bir biçimde karşılıklı bir etkileşim içindedir (Lewis, 2012: 116-117). Kırgızistan'da modern devletin en büyük dayanağı olan yürüyen bir hukuk üzerine inşa sistematik bir vergilendirme sisteminin yokluğu ve yolsuzluk sağlık bir siyasal sistemin ortaya çıkışını paralize etmektedir (Engvall, 2007). Benzer bir noktaya vurgu yapan Gürbüz (2013) devlet aygıtının kaynakların dağıtımı ve ülkesel bütünlüğü sağlayacak bir altyapı sağlayamamasını iç kırılganlığa kaynaklık eden iki büyük sorun olarak görür.

Öte yandan siyasal sistemin söz konusu yapısal eksikliği dış politikanın teşekkülüne de tesir etmektedir. Bu tespiti en vazıh şekilde, Kırgızistan örneğinde mütalaa etmek mümkündür. Çünkü dış politika içeride bir kişisel zenginleşme aracı olduğu kadar rejimlerin ayakta kalmasına yönelik desteğin sürdürülmesinde de payanda işlevi görmektedir. Bir başka deyişle liderlerin rant arayışının bir nedeni de aksak da olsa seçimlerin var olduğu demokratik bir yapıya sahip olan Kırgızistan'da patronajlarını devam ettirmektir (Cooley, 2012: 9; Toktomushev, 2015, 2016). Örneğin, Cooley, Orta Asya devletlerinin yoğun bölgesel rekabetten faydalandiklarına vurgu yapmaktadır. $\mathrm{Bu}$ çerçevede büyük güçler arasındaki mücadeleden beslenen "yerel aktörler" uluslararası güç mücadelelerini istismar etme eğilimindedir. $\mathrm{Bu}$ anlamda izlenen denge politikası aslında büyük güçlerden maksimum faydayı elde etmeye yönelik bir girişimden ibaret olarak görünmektedir. Bu nedenle rejimlerin temel kaygısı izleyebildikleri ölçüde denge politikasını sürdürmek ve bu denge politikası neticesinde farklı ülkerden kaynaklanan sermaye akışını devam ettirmektir (Cooley, 2012: 9-10). Sarı'da benzer bir noktaya vurgu yaparak Kırgızistan'ın dış politikasının iç politika ile bağlantısını şu şekilde kurmaktadır: “Kırgızistan'ın yönetici elitleri aynı amaca ulaşmak için farklı dış politikalar uyguladılar, örneğin, siyasal düzeni sağlamak ve kendi yerel pozisyonları için kritik dış destek edinmek için dış politikayı kullanmak gibi" (Sarı, 2012: 136). Öte yandan konuyu detaylandiran Toktomushev, rejimler kendi güvenliklerini sağlamak adına girdikleri rant arayışında yabancı hükümetler ve şirketler ile gayri resmi bağlar kurabilmektedirler (Toktomushev, 2015, 2016). Yine Toktomushev'e göre gerek Akayev gerekse de Bakiyev döneminde ABD üssüne ilişskin yapılan anlaşmaların arka planında liderlerin rant arayışı yatmaktadır (Toktomushev, 2015: 60). Aynı noktaya temas eden Cooley (2012: 143-146) de benzer şekilde Kırgızistan'da siyasi figürlerin askeri üs politikasının nasıl başarıyla bir rant aracına dönüştürdüğünü tafsilatlı bir şekilde izah etmektedir.

\subsection{Dıș Kırılganlık ve Diğer Ülkelerle İlișkiler}

Kırgızistan iç kırılganlıklar kadar dış politikada da sinırlılıklarla maluldür. Bu kapsamda Huskey'in not ettiği önemli bir nokta küçük bir devlet olarak Kırgızistan'ın, sahip olduğu "kırılganlık" nedeniyle sürekli bir denge politikası izlemek zorunda kalmış olduğudur (Huskey, 2008). Kuşkusuz bu denge politikasının alacağı şekil, dengeleyici aktörlerin gücü ve etkisi ile doğrudan ilişkilidir. Bir diğer deyişle küresel güç odaklarının Orta Asya ve daha özelde Kırgızistan'a yönelik politikalarının niteliği ve yoğunluğu
Kırgız otoritelerin bu ülkelerle olan ilişkileri için belirleyici olmuştur. Bunun yanı sıra Kırgızistan'ın küçük devlet olmasından kaynaklanan dışa bağımlılığı pek çok açıdan bağımsız bir dış politika izlemesini güçleştirmektedir. Söz konusu bağımlılıklar yalnızca küresel aktörler değil komşu bölge ülkeleri ile ilişkilerde de belirleyicidir. Bu çerçevede Kırgızistan ve Özbekistan arasındaki su ve sınır meselesi ile Kırgızistan'ın Özbekistan'a enerji bağımlılığı çözülemeyen önemli bölgesel sorunlar olarak bir kenarda durmaktadır (Huskey, 2008:6-7; Çotaev, 2017:334).

Kuşkusuz Kırgız dış politikası açısından en önemli aktörlerden biri Rusya Federasyonudur. Bir taraftan Sovyetler döneminden kalma kültürel ve tarihsel bağların varlığı, Soğuk Savaş sonrasında dahi Rus etkisinin ülkede hissedilmesi, diğer taraftan yeni elde edilmiş bağımsızlı̆̆ın korunması gayretleri 1990 sonrası dünyada Kırgızistan açısından önemli bir gerilim kaynağı olmuştur (Çotaev, 2017: 332; Sar1, 2012: 139). Sovyetlerin çöküşüne müteakip Rusya'nın Orta Asya coğrafyasında tedrici biçimde artan ağırlığı, diğer Orta Asya ülkelerinde olduğu gibi Kırgızistan'da hissedilmiştir. Bu çerçevede gerek Rusya'nın görece coğrafi yakınlığı gerekse de mevcut Rus üslerinin varlığ̀ Kırgızistan'1 Rus etkisine açık hale getirmiştir. Rusya ile kurulan ikili ilişkilerin yanında Şanghay İşbirliği Örgütü'nün çatısı altında Çin'i de kapsayacak biçimde daha geniş bir çerçevede kurgulanan hükümetler arası yapılar da mevcuttur. Kırgızistan ayrıca Rusya'nın Sovyet mirasını devam ettirme gayretinin bir ürünü olan Kolektif Güvenlik Anlaşması Örgütü ise bu anlamda bir diğer çok uluslu organizasyon niteliğindedir. Tüm bunlara ek olarak Avrasya Ekonomik Birliği taraflar arası ilişkilerin ekonomik ayağını teşkil etmiştir (Çotaev, 2017: 333). Ayrıca Rusya'da çalışan çok sayıda Kırgız işçinin katkısı Kırgızistan ekonomisi açısından hayati bir öneme sahiptir (Aitymbetov, 2006; Huskey, 2008: Akmoldoev ve Budaichieva, 2012: 55-56). Ekonomik etkiye verilebilecek bir diğer örnek ise Rusya ile kurulmuş olan bir takım finansal ilişkilerden kaynaklanmaktadır. Rusya'nın askeri üs anlaşmasını 15 yıl uzatması, 500 milyon dolarlık borcu silmiş olması ve ekonomiyi rahatlatması bir diğer önemli faktördür (Dzyubenko, 2014). Rusya'nın hızla artan etkisi ile beraber Kırgızistan'ın denge politikası izlemesi de giderek güçleşmektedir (Huskey, 2008: 17-18). Özellikle son yıllarda gün yüzüne çıkan Avrasya Ekonomik Birliği projesi aynı zamanda Rusya'nın diğer Orta Asya ülkeleri gibi Kırgızistan üzerindeki ekonomik hegemonyasını pekiştirecek bir adım olarak okunmaktadır (Kirkham, 2016). 2000'li yıllardan itibaren Rusya-Orta Asya ilişkilerinde bir diğer önemli konu Soğuk Savaş sonrası süreçte yükselen radikalizm olmuştur. Bu anlamda Rusya'nın sağladığı askeri destek önemli hale gelmiştir. (Cummings, 2001: 150).

Tüm bunların yanında Rusya muazzam istihbari gücüyle Post-Sovyet coğrafyanın farklı ülkelerinde etkili olmuştur. Rusya genellikle manipülasyon silahını kullanarak farklı şekillerde kendine yakın hükümetleri desteklemiştir (Way, 2015; Babayan, 2015; Lutz vd., 2019). Rusya'nın etkisi Kırgızistan iç politikasında oldukça görünür bir niteliğe haizdir. Akayev'den Ceenbekov'a kadar tüm liderlerin Rusya ile sahip olduğu ikili ilişkiler Kırgızistan politikasında belirleyici bir motif olmuştur. Yine Kırgızistan'da 2005 ve 2010 yıllarında yaşanan devrimlerde Rusya'nın aldığ pozisyon liderlerce yakından takip edilmiştir. Öyle ki yeni liderler kadar devrik liderlerin de genellikle ilk durakları 
Rusya olmuştur. Özellikle Rusya’nın Kırgızistan'da sahip olduğu medya gücü kamuoyunu şekillendirecek önemli bir propaganda aracına dönüşmüştür. Nitekim Bakiyev'in gönderilme sürecinde yolsuzluklara vurgu yapan Rus kaynaklı medya kampanyası devrimi hazırlayan şartlardan biri haline gelmiştir (Çotaev, 2017: 344; Kramer, 2010).

Yakın dönemde yaşanan bir takım gelişmeler de bölgesel güç dengesinde belirgin bir değişim ortaya çıkarmıştır. Şöyle ki; ABD'nin geri çekilmesi Kırgızistan'ın uzun süre sürdürmeyi becerdiği denge politikasının da sekteye uğraması anlamına gelmiştir. Aslında daha geniş bir perspektiften düşünüldüğünde yaşanan süreç bir bütün olarak Batı'nın Orta Asya'dan geri çekilmesidir. Bu kapsamda 2017 yılında NATO'nun Taşkent'deki ofisinin kapatılması sembolik bir anlam taşımaktadır (Kucera, 2017). $\mathrm{Bu}$ nedenle Rusya'nın bölgede giderek artan etkisinin tarihsel, ekonomik ve siyasal motifleri olmasına karşın aynı zamanda bir bütün olarak Batı'nın daha özelde ABD'nin giderek zayıflayan bölgesel tesiri ile bağlantılıdır. Obama döneminde hızlanan geri çekilme süreci Kırgızistan örneğinde 2013 yılında Manas üssünün kapatılması ile başlamıştır (Dzyubenko, 2014). Trump dönemi ABD dış politikasına damgasını vuran tartışma ise ABD'nin giderek daha izolasyonist bir politika izlemekte olduğudur. Jacksonyen bir geleneğin temsilcisi olduğu kaydedilen Trump'un bu düzlemde doğrudan güvenlik tehditlerine odaklanan temel meseleler dışında dış politikayı bütünüyle rafa kaldırdığı iddia edilmektedir (Cha, 2016). Avrupa Birliği ise genellikle normatif değerlere yaptığ 1 vurgu üzerinden bu ülkelerde yumuşak güce dayalı bir siyaseti hedeflemiştir. Bununla birlikte somut/maddi unsurlarla desteklenmeyen pek çok $\mathrm{AB}$ değerinin bugün Orta Asya ülkelerinde bir karşılığı bulunmamaktadır (Kavalski ve Cho, 2018: 63).

Daha geniş bir çerçevede benzer bir noktaya temas eden Cooley (2019) aslında bir bütün olarak Post-Sovyet coğrafyada bir Batı projesi olarak liberal uluslararasıcılığın sonuna gelindiğine işaret etmektedir. Öyle ki Batı merkezli politik öneriler başta Özbekistan olmak üzere diğer bölge ülkeleri ve Rusya-Çin ekseni tarafından kaygı verici kabul edilmiştir (Huskey, 2008: 8; ayrıca bkz. Cooley, 2019). Diğer taraftan bir bütün olarak Batı felsefesi ve bu felsefenin ürünü olan değerler karşısında başını Rus entellektüellerin çektiği Avrasyacılık düşüncesi Orta Asya'da dahil olmak geniş bir coğrafyayı etkilemiştir (bkz. İsmayilov, 2008:227232; İmanov, 2011, Serbest, 2017). Bugün Avrasyacılık pek çok Orta Asya ülkesi için alternatif bir ideolojik akım olarak geçerliliğini sürdürmektedir.

Özetle ABD'nin dünya siyasetinde hedef küçültmesi ve AB'nin ise değerler üzerinden yürüttüğü politikasının alıcısı olmaması Kırgızistan'ın dâhil olduğu büyük bir coğrafyayı Rusya'nın etki alanına bırakılması anlamını taşımıştır. Rusya'nın mevcut hegemonyasına alternatif tek ülke ise etkisi giderek artan Çin Halk Cumhuriyeti'dir. Bu anlamda Kırgızistan'ın geleceğinde Çin-Rus rekabeti ihtimal dâhilindedir. (Çotaev, 2017: 361) Bununla birlikte Çin'in Orta Asya politikasının başta gaz ve petrol olmak üzere enerji ihtiyaçlarını karşılamak olduğu unutulmamalıdır (Swanström, 2005; Xu, 1999). Çin açısından Sincan meselesi ise ikinci büyük sorun alanını oluşturur. Özellikle Uygur ayrılıkçılığına yapılan vurgu çerçevesinde Çin Orta Asya ülkeleri ile güvenlik temelli bir takım anlaşmalar imzalanmıştır. Bu çerçevede Şangay İşbirliği Örgütü radikalizm ile mücadele söylemi etrafında Çin tarafından işlevselleştirilmektedir (Kerr ve Laura, 2008). Kısacası Orta Asya'nın ve daha özelde Kırgızistan'ın kısa vadede bağımsız politika izleme şansı oldukça sınırlı iken yeni dengeleri gözetmesi elzem görünmektedir.

\section{Sonuç ve Değerlendirme}

Kırgızistan 1990 sonrasında bağımsızlığını kazanan diğer pek çok ülkede olduğu gibi geçmişin yükünü üzerinde taşımıştır. Bir taraftan bağımsızlığına yeni sahip olmasının getirdiği egemenliğini dışarıya karşı koruma kaygısı diğer taraftan geçmişten tevarüs eden bölgesel sorunlar, Soğuk Savaş sonrası dönemde de Kırgızistan dış politikası açısından belirleyici olmuştur. Bununla birlikte pek çok açıdan küçük devlet olma özelliklerini taşıyan Kırgızistan'ın izlediği politika, küresel ve bölgesel güç dengesini korumayı da zorunlu kılmaktadır. Bu çalışma ile Ceenbekov dönemi siyaset değerlendirilirken diğer taraftan da Kırgız dış politikasına dair Türkçe literatüre bir katkı yapılması amaçlanmıştır. Mevcut analiz kapsamında yapılan tanım gereği küçük devletler aynı zamanda içsel kırılganlıklara da sahiptir. Ekonomik yetersizliklerle bağlantılı olarak yolsuzluk, neopatrimonyalizm ve en genel anlamıla kötü yönetişim Kırgız siyasetinin sağlıklı bir zeminde işleme imkânını ortadan kaldırmaktadır. Devletlerin söz konusu kırılganlıkları aynı zamanda diğer küresel ve bölgesel güçlerle ilişkilerinde belirleyici olmaktadır. Ceenbekov dönemi dış politikasının incelendiği bu çalışmada Atambayev sonrası gerçekleşen değişimin dış politikanın karakterinde köklü bir değişiklik yaratmadığı iddia edilmektedir. Özellikle 2001 sonrasında görünürlüğü giderek artan ABD'nin Afganistan ve Orta Asya coğrafyasından askeri olarak çekilmesinin tüm ülkeler açısından önemli sonuçlar doğurduğu vazıhtır. Nitekim bu çalışmada da ABD'nin aşamalı olarak etkisini yitirmesi ile beraber özellikle Atambayev'in iktidarından bu yana Rusya'nın bölgesel oyun kurucu olarak Kırgızistan dış politikasına tesir edebildiği vurgulanmaktadır. Söz konusu etki Ceenbekov döneminde de kesintisiz devam etmiştir. Zira Kırgız karar vericiler için iç politik istikrarı ve ekonomik gönenci sağlamak için tek geçerli seçenek Rusya haline gelmiştir. Öte yandan ABD'nin bölgeden çekilişinin bir yönüyle Kırgızistan'ın pazarlık imkânlarını sınırladığı iddia edilebilecektir. Bununla birlikte ABD'nin yerinin farklı güçlerce doldurulması muhtemeldir. Zira şu an halen ekonomik bir güç olarak varlığını sürdüren Çin'in uzun vadede siyasal ve askeri bir güç olarak Rus hegemonyasına alternatif oluşturabileceği olasılığı göz ardı edilmeyecek kadar önemlidir.

\section{Kaynakça}

Aitymbetov, S. (2006). Emigrant remittances: Impact on economic development of Kyrgyzstan. (ICEG, European Centre, Working Paper 31, Budapest)

Akmoldoev, K., \& Budaichieva, A. (2012). The impact of remittances on Kyrgyzstan economy. Reforma (Реформа), 4, 53-59. 
Alkan, H. (2012). Türk Cumhuriyetlerinde Siyasal Kurumsallasma Süreci: Geçen Yirmi Yılın Bir Bilançosu. Bilig, 61, 1-30.

Babayan, N. (2015). The return of the empire? Russia's counteraction to transatlantic democracy promotion in its near abroad. Democratization, 22(3), 438-458.

Bailes, A. J., Thayer, B. A., \& Thorhallsson, B. (2016). Alliance theory and alliance 'Shelter': the complexities of small state alliance behaviour. Third World Thematics: A TWQ Journal, 1(1), 9-26.

BBC. (2018, 27 Şubat). Kyrgyzstan country profile. Erişim Adresi https://www.bbc.com/news/world-asia16186907

Bishop, M. L. (2012). The political economy of small states: Enduring vulnerability? Review of International Political Economy, 19(5), 942-960.

Brown, D. R. (2010). Institutional development in small states: Evidence from the Commonwealth Caribbean. Administrative Culture, 11(1), 44-65.

Cha, T. (2016). The Return of Jacksonianism: the International Implications of the Trump Phenomenon. The Washington Quarterly, 39(4), 8397.

Chong, A. (2010). Small state soft power strategies: virtual enlargement in the cases of the Vatican City State and Singapore. Cambridge Review of International Affairs, 23(3), 383-405.

Coldoşov, A. (2017). Kırgızistan'ın iç Politikası. İçinde Cengiz Buyar (Ed.). Kırglzistan: Tarih-ToplumEkonomi-Siyaset. (s.245-286), Bişkek: BYR Publishing.

Cooley, A. (2012). Great games, local rules: The new power contest in central Asia, New York: Oxford University Press.

Cooley, A. (2019). Ordering Eurasia: The rise and decline of liberal internationalism in the post-communist space. Security Studies, 28(3), 588-613.

Cooper, A. F., \& Shaw, T. M. (2009). The Diplomacies of small states at the start of the twenty-first century: How vulnerable? How resilient? İçinde Cooper, A. F., \& Shaw, T. M (Ed.), The diplomacies of small states (s.1-18) New York: Palgrave.

Cummings, S. (2001). Happier bedfellows? Russia and central Asia under Putin. Asian Affairs, 32(2), 142152.

Çotaev, Z. (2017). Kırgızistan'ın Dış Politikası : Devam Eden ve Değişen Eğilimler. In Cengiz Buyar (Ed.), Klrglzistan: Tarih-Toplum-Ekonomi-Siyaset (s. 319376). Bişkek: BYR Publishing.

Dzyubenko, O. (2014, 3 Haziran). U.S. vacates base in Central Asia as Russia's clout rises. Reuters. Erișim Adresi https://www.reuters.com/article/uskyrgyzstan-usa-manas/u-s-vacates-base-in-centralasia-as-russias-clout-risesidUSKBNOEE1LH20140603
Engvall, J. (2007). Kyrgyzstan: Anatomy of a state. Problems of Post-Communism, 54(4), 33-45.

Euroasianet. (2019, 24 Ekim). Explainer: How did Kyrgyzstan's ex-president fall so low? Erişim Adresi https://eurasianet.org/explainer-how-didkyrgyzstans-ex-president-fall-so-low

Gibert, M. V., \& Grzelczyk, V. (2016). Non-Western small states: activists or survivors? Third World Thematics: A TWQ Journal, 1(1), 2016.

Gleason, G., Kerimbekova, A., \& Kozhirova, S. (2008). Realism and the small state: evidence from Kyrgyzstan. International Politics, 45(1), 40-51.

Golovnina, M., \& Solovyov, D. (2010, 6 Nisan). New Kyrgyz rulers hail Russia, aim to shut U.S. base. Reuters. Erişim Adresi https://www.reuters.com/article/us-kyrgyzstanunrest/new-kyrgyz-rulers-hail-russia-aim-to-shut-us-base-idUSTRE6363CR20100408.

Gürbüz. Y. E. (2013). Kyrgyzstan: In search for stability. Insight Turkey 15(4), 191-205.

Handel, M. I. (2016). Weak states in the international system. New York: Routledge.

Hermann, C. F. (1990). Changing Course: When Governments Choose to Redirect Foreign Policy. International Studies Quarterly, 34(1), 3-21.

Huskey, E. (2008). Foreign Policy in a Vulnerable State: Kyrgyzstan as Military Entrepot Between the Great Powers. China \& Eurasia Forum Quarterly 6 (4), 5 18.

İmanov, M. (2011). Avrasyacılık Mukayeseli Bir Okuma Türkiye ve Rusya Örneği, İstanbul: Doğu Batı Yayınları.

İsmayılov, V. (2008). Avrasyacılık Rusya'nın Kimlik Arayışı, İstanbul: Küre Yayınları

Kabar. (2019, 25 Aralık). Kyrgyzstan's future lies in EAEUPresident Jeenbekov. Erişim Adresi http://en.kabar.kg/news/future-of-kyrgyzstantogether-with-the-eaec-president-jeenbekov/

Karsh, E. (2012). Neutrality and small states New York: Routledge.

Kavalski, E., \& Cho, Y. C. (2018). The European Union in Central Eurasia: still searching for strategy. Asia Europe Journal, 16(1), 51-63.

Kerr, D., \& Laura C, S. (2008). China, Xinjiang, And The Transnational Security Of Central Asia. Critical Asian Studies, 40(1), 89-112.

Kirkham, K. (2016). The formation of the Eurasian Economic Union: How successful is the Russian regional hegemony? Journal of Eurasian Studies, 7(2), 111-128.

Kramer, A. E. (2010, 18 Nisan). Before Kyrgyz Uprising, Dose of Russian Soft Power. The New York Times. Erişim Adresi https://www.nytimes.com/2010/04/19/world/asia/19 kyrgyz.html 
Kucera, J. (2017, 17 Kasım ). NATO Closes Shop in Central Asia. Euroasianet. Erişim Adresi https://eurasianet.org/nato-closes-shop-central-asia

Lewis, D. (2012). Understanding the Authoritarian State: Neopatrimonialism in Central Asia. The Brown Journal of World Affairs, 19(1), 115-126.

Lutz, C. K., Lutz, B. J., \& Lutz, J. M. (2019). Russian Foreign Policy Management and Manipulation with the Soviet Successor States. Terrorism and Political Violence, 31(1), 84-97.

MENAFN - Trend News Agency. (2018, 20 Kasım). Sooronbay Jeenbekov's work results in foreign policy in his one year presidency. MENAFN. Erişim Adresi https://menafn.com/1097723401/SooronbayJeenbekovs-work-results-in-foreign-policy-in-hisone-year-presidency

Moon, B. E. (2009). Consensus or compliance? Foreignpolicy change and external dependence. International Organization, 39(2), 297-329.

Muzalevsky, R. (2010). The US-Kyrgyz military center and Kyrgyzstan's multi-vector foreign policy. Central Asia-Caucasus Analyst, 5, 12-14.

Radio Free Europe/ Radio Liberty. (2018, November, 27). New Kyrgyz President Vows Balanced Foreign Policy With Russia As Main 'Strategic Partner'. Radio Free Europel Radio Liberty. Erişim Adresi https://www.rferl.org/a/kyrgyzstan-jeenbekov-vowsbalanced-foreign-policy-russia-strategicpartner/28883735.html

Sar1, Y. (2012). Foreign Policy of Kyrgyzstan under Askar Akayev and Kurmanbek Bakiyev. Perceptions: Journal of International Affairs, 17(3), 131-150.

Serbest, M.B. (2017). Tarihsel Süreçte Rus Avrasyacılığı: Klasik Avrasyacılıktan Neo-Avrasyacılığa. Manas Sosyal Araştırmalar Dergisi, 6(3), 285-307.
Sutton, P. (2011). The concept of small states in the international political economy. The round table, 100(413), 141-153.

Swanström, N. (2005). China and Central Asia: a new Great Game or traditional vassal relations? Journal of Contemporary China, 14(45), 569-584.

Thorhallsson, B., \& Wivel, A. (2006). Small States in the European Union: What Do We Know and What Would We Like to Know? Cambridge Review of International Affairs, 19(4), 651-668.

Toktomushev, K. (2015). Regime security, base politics and rent-seeking: the local and global political economies of the American air base in Kyrgyzstan, 2001-2010. Central Asian Survey, 34(1), 57-77.

Toktomushev, K. (2016). Kyrgyzstan-Regime Security and Foreign Policy New York: Routledge.

Tür, Ö., \& Salık, N. (2017). Uluslararası İlişkilerde "Küçük Devletler" Gelişimi, Tanımı, Dış Politika ve İttifak Davranışları. Uluslararası İlişkiler/International Relations, 14(53), 3-22.

Waltz, K. N. (1979). Theory of international politics (1st ed.). Boston, Mass.: McGraw-Hill.

Way, L. A. (2015). The limits of autocracy promotion: The case of Russia in the 'near abroad'. European Journal of Political Research, 54(4), 691-706.

Worldbank. (2019). Overview. Erişim Adresi https://www.worldbank.org/en/country/kyrgyzrepubl ic/overview

Xu, X. (1999). The Oil and Gas Links Between Central Asia and China: a Geopolitical Perspective. OPEC Review, 23(1), 33-54.

Yeşilyurt, N . (2015). Ürdün'ün Bölgesel Konumu: Küçük Devlet Kavramı Çerçevesinde Bir İnceleme. Ankara Üniversitesi SBF Dergisi , 70 (2) , 377-401 